\title{
Antisecretory Action of the Extract of the Aerial Parts of Eremomastax speciosa (Acanthaceae) Occurs through Antihistaminic and Anticholinergic Pathways
}

\author{
Amang André Perfusion, ${ }^{1,2}$ Paul V. Tan, ${ }^{1}$ Nkwengoua Ernestine, ${ }^{3}$ and Nyasse Barthélemy ${ }^{3}$ \\ ${ }^{1}$ Department of Animal Biology \& Physiology, Faculty of Science, P.O. Box 812, University of Yaoundé I, Yaoundé, Cameroon \\ ${ }^{2}$ Department of Biological Sciences, Faculty of Science, P.O. Box 46, University of Maroua, Maroua, Cameroon \\ ${ }^{3}$ Department of Organic Chemistry, Faculty of Science, P.O. Box 812, University of Yaoundé I, Yaoundé, Cameroon \\ Correspondence should be addressed to Paul V. Tan; pvernyuy@yahoo.com
}

Received 11 September 2013; Revised 3 January 2014; Accepted 6 January 2014; Published 20 February 2014

Academic Editor: Masahiro Oike

Copyright (C) 2014 Amang André Perfusion et al. This is an open access article distributed under the Creative Commons Attribution License, which permits unrestricted use, distribution, and reproduction in any medium, provided the original work is properly cited.

\begin{abstract}
Objective. The objective of this study was to find out the possible antiulcer mechanism of action of Eremomastax speciosa. Method. Carbachol- and histamine-induced hypersecretion, associated with the pylorus ligation technique, were used in rats. Gastric mucosal ulceration, mucus production, $\mathrm{pH}$, gastric volume, and acidity were measured. Results. Histamine and carbachol raised gastric acidity to 86.50 and $84.80 \mathrm{mEq} / \mathrm{L}$, respectively, in the control rats, and the extracts $(200 \mathrm{mg} / \mathrm{kg})$ reduced gastric acidity to 34.60 and $39.00 \mathrm{mEq} / \mathrm{L}$, respectively. Intraduodenal aqueous extract $(400 \mathrm{mg} / \mathrm{kg})$ in histamine- and carbachol-treated rats produced significant $(P<0.001)$ decreases in acid secretion to 28.50 and $28.80 \mathrm{mEq} / \mathrm{L}$, respectively, and 100 percent inhibition of gastric ulceration. Augmented histamine-induced gastric acid secretion $(90.20 \mathrm{mEq} / \mathrm{L})$ was significantly reduced to 52.60 and $27.50 \mathrm{mEq} / \mathrm{L}$ by the 200 and $400 \mathrm{mg} / \mathrm{kg}$ doses of the aqueous extract, respectively. The extract significantly reduced $(P<0.001)$ the volume of gastric secretion and significantly increased mucus production. The ulcer inhibition potential of the extract significantly dropped to $25-44 \%$ (oral extract) and to 29-37\% (duodenal extract) in carbachol/indomethacin-treated rats. Conclusion. The aqueous extract of E. speciosa has both cytoprotective and antisecretory effects. The antisecretory effect may involve a mechanism common to both cholinergic and histaminergic pathways.
\end{abstract}

\section{Introduction}

The central role of gastric acid hypersecretion in the etiology of gastroduodenal ulcers, gastrooesophageal reflux disease and gastric cancer is well known. Thus, while ulcers are almost always present in patients with Zollinger-Ellison syndrome, which is characterised by excessively high gastric acid secretion, they are absent in achlorhydric patients. The gastric acid hypersecretion can be of stress or genetic origin but can as well result from the interaction between a genetic component with environmental factors $[1,2]$. Outstanding findings in the understanding of peptic ulcer etiology include the discovery histamine $\mathrm{H}_{2}$-receptors, the $\mathrm{H}^{+} \mathrm{K}^{+}$-ATPase-driven parietal cell pump by the end of the 1970s, and the more recent discovery of the role of Helicobacter pylori in the development of duodenal ulcer by [3]. Corresponding breakthroughs in the treatment of acid-peptic disorders include the discovery of the prototypical $\mathrm{H}_{2}$ antagonist, cimetidine, developed by Smith, Kline; and French (now GlaxoSmithKline) in the midto-late 1960s [4], the development of proton pump inhibitors $[5,6]$, and the development of the $H$. pylori triple therapy eradication regimens $[7,8]$.

The FDA-approved triple therapy regimen includes a proton pump inhibitor (Omeprazole, Lansoprazole, or pantoprazole) + Clarithromycin and Metronidazole (or Amoxicillin) or a $\mathrm{H}_{2}$-receptor antagonist (Cimetidine or Ranitidine) + Bismuth and antibiotics (Clarithromycin and Metronidazole (or Amoxicillin)) [9-11]. Unfortunately, H. pylori strains resistant to the commonly prescribed antibiotics have emerged. In addition, the high cost of the triple therapy 
regimen, especially for patients in poor countries, and the adverse effects associated with the antibiotics and antisecretory agents have been at the root of low patient compliance, treatment failures, and recurrence of treated ulcers [1215]. For example, the reported adverse effects in patients taking Cimetidine involve various organ systems including the gastrointestinal system (diarrhea, constipation), central nervous system (psychosis, depression, and anxiety especially in the elderly), endocrine system (gynecomastia, reversible impotence), hepatobiliary system (dose-related increase in serum transaminases, occasional liver injury), renal system (dose-related increase in plasma creatinine) and cardiovascular system (rare cases of bradycardia and tachycardia). The three well-known disease interactions with Tagamet include liver disease, hemodialysis, and renal dysfunction, while drug interactions with Tagamet include 18 major, 336 moderate, and 317 minor ones. This litany of possible side effects associated with the most prescribed antisecretory agent underlines the current need to intensify the search for antisecretory materials from local medicinal plant sources. Other workers [16] have given a detailed description of the roles of extracellular calcium, histamine and $\mathrm{H}_{2}$ receptors, and acetylcholine and muscarinic $\left(\mathrm{M}_{3}\right)$ receptors in the mechanism of gastric secretion, and our previous work [17] describes many medicinal plants with proven antisecretory activities. Some of the plants have provided active extracts, fractions, and compounds with anticholinergic or antihistaminic activity. Botanical compounds with antiulcer activity include flavonoids (i.e., quercetin, naringin, silymarin, anthocyanosides, and sophoradin derivatives), saponins (i.e., from Panax japonicus and Kochia scoparia), tannins (i.e., from Linderae umbellatae), gums, and mucilages (i.e., gum guar and myrrh). Among herbal drugs, liquorice, aloe gel, and capsicum (chilli) have been used extensively and their clinical efficacy documented. The cytoprotective, antioxidant, anti-inflammatory, and antiulcer activities of flavonoids, alkaloids, triterpenoids, and polyphenols have been demonstrated experimentally [17-20]. Comparative phytochemical screening of two species of Eremomastax revealed the presence of flavonoids, alkaloids, phenols, tannins, terpenes, and saponins [21]. A comprehensive review of drugs derived from botanical sources more commonly used or extensively studied in the world for peptic ulcer has been published [22].

Eremomastax speciosa (Hochst.) Cufod. (Acanthaceae) is widespread from West Africa through Central African Republic and $\mathrm{N}$ Congo-Kinshasa to S Sudan and SW Ethiopia, Madagascar. The plant is widely distributed in tropical Africa and is the only species of the genus Eremomastax (syn.: Paulowilhelmia (Lindau) and Ruellia (S. Moore)) [23]. It is a robust, polymorphous shrub that grows to $2 \mathrm{~m}$ high and has a characteristic quadrangular stem and violate underside of the leaves which has earned for it the local name Pang nyemshe, meaning "red on one side" in the Bamileke region of Cameroon.

The plant is commonly referred to in Cameroon as "blood plant" due to its reputed use in the treatment of cases of anemia. It is also used in Cameroonian ethnomedicine for the treatment of various stomach complaints and information from tradipractitioners suggested that it possesses antiulcer effects. The antidiarrhoeal activity of E. speciosa leaf aqueous extract has been reported [24]. The leaf extract is used for the treatment of male infertility among the Ifa Nkari People of Akwa Ibom State, Nigeria (where it is known commonly as "golden seal;" "African blood tonic plant;" local name, Edem Ididout, Ndana-edem) [25]. Its widelyclaimed antianaemic activity has been experimentally demonstrated by workers [26] who also showed anti-microbial actions against pure clinical cultures of Staphylococcus aureus, E. coli, Candida albicans, and Aspergillus niger. The Douala people of Cameroon employ E. speciosa variously for malaria, kidney pain, scabies anaemia diabetes, and nerves pain [27]. E. speciosa has been cited for its local use in the treatment of female infertility in the west region of Cameroon [28], as well as for its use in the treatment of irregular menstruation by the Aguambu-Bamumbu people of the Lebialem highlands in the South West Region of Cameroon [29]. The plant has also been cited [30] for the treatment of menstrual pains, gonorrhea, appendicitis, and dry burns and as an antipoison, and to increase and purify blood in the mount Cameroon region.

In spite of the wide gastrointestinal ethnopharmacological potential of E. speciosa, the only literature report to date on its antiulcer activity is the preliminary study [31] which showed that the water extract significantly inhibited the formation of $\mathrm{HCl} /$ ethanol-inflicted gastric lesions in rats. Recently, we have demonstrated the activity of the methanol extract against various experimental ulcer models including $\mathrm{HCl} /$ ethanol, absolute ethanol, cold/restraint stress, and indomethacin [32]. In the present experiment we employed the pylorus ligated technique in a series of secretagogueinduced hypersecretion models in order to study the possible mechanism of action of E. speciosa.

\section{Material and Methods}

\subsection{Material}

2.1.1. Animals. Male albino Wistar rats (180-220 g) raised in the Animal house of the Animal Physiology laboratory, Faculty of Science, University of Yaounde I, were used. They were fed a standard laboratory diet (supplied by SPC Ltd., Bafoussam, Cameroon) and given tap water ad libitum. The animals were deprived of food prior to experimentation but access to water was maintained. Prior authorization for the use of laboratory animals in this study was obtained from the Cameroon National Ethics Committee (Reg. no. FWAIRB00001954). The use, handling, and care of animals were done in adherence to the European Convention (Strasbourg, 18.III.1986) for the protection of vertebrate animals used for experimental and other purposes (ETS-123), with particular attention to Part III, articles 7, 8, and 9.

\subsection{Methods}

2.2.1. Preparation of the Plant Extracts and Fractions. The aerial parts of E. speciosa were collected in May/June 2012 in Yaounde (centre region) and identified botanically by Paul Mezili of the Cameroon National Herbarium (by comparison 
with existing voucher specimen $\left.\mathrm{N}^{\circ} \mathrm{HNC} / 136984\right)$. They were chopped, rapidly dried under room temperature $\left(25^{\circ} \mathrm{C}\right)$ for one week, and transformed into powder. $3796 \mathrm{~g}$ of powder was macerated in $15 \mathrm{~L}$ of a $2: 1(\mathrm{v} / \mathrm{v})$ mixture of methanol and methylene chloride, which was the highest yielding out of the five extraction solvents tested for $72 \mathrm{~h}$ at room temperature. After filtration through Wattman filter paper number 3 and sequential evaporation at $40^{\circ} \mathrm{C}$ and $65^{\circ} \mathrm{C}$ in a rotavapor to remove the methylene chloride and methanol, respectively, $318 \mathrm{~g}$ of crude extract was obtained (8.4\% yield). $159 \mathrm{~g}$ of crude extract was fractionated with hexane $(1 \mathrm{~L})$, methylene chloride $(0.5 \mathrm{~L})$, ethyl acetate $(0.25 \mathrm{~L})$, and methanol $(0.125 \mathrm{~L})$, respectively, to obtain $39.3 \mathrm{~g}$ of hexane fraction (24.7\% yield), $30.5 \mathrm{~g}$ of methylene chloride fraction (19.2\% yield), $5.6 \mathrm{~g}$ of ethyl acetate fraction (3.52\% yield), and $3.3 \mathrm{~g}$ of methanol fraction (2.1\% yield).

Aqueous Extract. $500 \mathrm{~g}$ of ground powder was extracted by infusion in 4 litres of boiled water for 15 minutes. After filtration through Wattman filter paper number 3 , the filtrate was evaporated using a Raven convection air oven (JenconsPLS, UK). The brownish solid obtained (77.7 g (15.5\% yield)) was stored at $4^{\circ} \mathrm{C}$. The crude extracts and fractions dissolved readily in distilled water which was used as vehicle in the subsequent experiments.

2.2.2. Phytochemical Tests. Phytochemical tests for major secondary metabolites of the extracts and fractions were performed. They were screened for the presence of biologically active compounds such as alkaloids, anthocyanins, and cardiac glycosides [33]; phenols and flavonoids [34]; triterpenes and sterols [35]; saponins [36]; anthraquinones, hydrolysable, and condensed tannins [37]; and coumarins [38]. Based on the intensity of coloration or the precipitate formed during the test, secondary metabolites proportion was characterized as strongly present $(+++)$, present $(++)$, weakly present $(+)$, and absent $(-)$ when the test result was negative; it was characterized as strongly present $(+++)$, present $(++)$, weakly present $(+)$ and absent $(-)$ when the test result was negative.

\subsubsection{Pylorus Ligated Gastric Secretion: Screening of Extracts} and Fractions for Antisecretory Activity. Fifty male rats (5 per group) were used to screen the aqueous, methanol, and methanol/methylene chloride $\left(\mathrm{Me}-\mathrm{CH}_{2} \mathrm{Cl}_{2}\right)$ extracts and the methylene chloride $\left(\mathrm{CH}_{2} \mathrm{Cl}_{2}\right)$, ethyl acetate, and hexane fractions for their antisecretory potential. Following a $48 \mathrm{~h}$ fast, the extracts, fractions, and vehicle were administered by oral route to the test and control rats, respectively, before the experiment. One hour later, laparotomy was performed under light ether anaesthesia and the pylorus of each rat was tied and the abdominal incisions were closed. The rats were sacrificed $6 \mathrm{~h}$ later and the gastric juice produced by each was collected, centrifuged, and the volume measured. The ulcers formed in the glandular region of the stomachs were scored as previously described [39].

2.2.4. Secretagogue-Induced Gastric Hypersecretion. Following the screening experiment, the aqueous extract, $\mathrm{CH}_{2} \mathrm{Cl}_{2}$ fraction, and $\mathrm{MeOH}-\mathrm{CH}_{2} \mathrm{Cl}_{2}$ extract, which induced the highly significant reductions in gastric acidity, were retained for the next set of experiments. Thus, the two extracts and $\mathrm{CH}_{2} \mathrm{Cl}_{2}$ fraction $(200 \mathrm{mg} / \mathrm{kg})$ were administered by oral route and tested on gastric secretion induced in pylorus ligated rats by histamine $(2.5 \mathrm{mg} / \mathrm{kg}$, s.c.) or carbachol $(1 \mathrm{mg} / \mathrm{kg}$, s.c.) injected $1 \mathrm{~h}$ after pylorus ligature [39]. The animals were sacrificed $4 \mathrm{~h}$ after secretagogue administration and gastric juice was collected and ulcer indices measured. The hypersecretory effects of the secretagogues were also challenged by the aqueous extract alone $(200-400 \mathrm{mg} / \mathrm{kg}$ ) administered by intraduodenal route. After laparotomy and pylorus ligation, the extract was introduced into the duodenal lumen using a syringe. The stomach incisions were closed and histamine $(2.5 \mathrm{mg} / \mathrm{kg})$ or carbachol $(1 \mathrm{mg} / \mathrm{kg})$ were administered $1 \mathrm{~h}$ later by subcutaneous route [40]. The animals were sacrificed $4 \mathrm{~h}$ after secretagogue administration. Gastric juice was collected and mucus production and ulcer indices were measured.

2.2.5. Augmented Histamine-Induced Gastric Secretion. A modification of the classic augmented histamine test was used to study the effect of the aqueous extract of E. speciosa (200 and $400 \mathrm{mg} / \mathrm{kg}$ ) in rats challenged with prolonged maximal circulating levels of histamine. The test and control rats were given the extract and vehicle, respectively, by oral route 30 minutes before pylorus ligation. The positive control rats received ranitidine $(100 \mathrm{mg} / \mathrm{kg})$. Histamine dihydrochloride $(1 \mathrm{mg} / \mathrm{kg}, \mathrm{s.c})$ was administered 4 times at hourly intervals. The gastric juice was collected $1 \mathrm{~h}$ after the last histamine injection and prepared for gastric acid analysis.

2.2.6. Nonsteroidal Anti-Inflammatory Drug (NSAID)-Induced Gastric Ulcers in Carbachol-Treated Rats. A modification of the method of Rainsford [41] was used. Gastric ulcers were induced, following a $24 \mathrm{~h}$ fast, using indomethacin $(30 \mathrm{mg} / \mathrm{kg}$, s.c. $)$ and carbachol $(0.5 \mathrm{mg} / \mathrm{kg}$, s.c. $)$ in pylorus ligated rats. The aqueous extract of E. speciosa (200$400 \mathrm{mg} / \mathrm{kg})$, ranitidine $(100 \mathrm{mg} / \mathrm{kg})$, and vehicle were administered orally 30 minutes before pylorus ligation. An hour after pylorus ligation, indomethacin $(30 \mathrm{mg} / \mathrm{kg}$, s.c.) and carbachol $(0.5 \mathrm{mg} / \mathrm{kg}$, s.c. $)$ were administered. After $4 \mathrm{~h}$ the animals were sacrificed by deep ether anesthesia and the gastric secretion was collected and gastric ulceration and mucus production measured. In a second experiment, the effect of the extract administered by duodenal route was tested: immediately following pylorus ligation, the extract $(200-400 \mathrm{mg} / \mathrm{kg}$ ) was injected into the duodenal lumen, the abdomen stitched up, and indomethacin $(30 \mathrm{mg} / \mathrm{kg}$, s.c.) and carbachol $(0.5 \mathrm{mg} / \mathrm{kg}$, s.c.) were injected an hour later. Another $4 \mathrm{~h}$ later, the animals were sacrificed and the gastric secretion, gastric ulceration, and mucus production were measured.

2.2.7. Measurement of Gastric Acidity. Samples of centrifuged gastric juice $(1 \mathrm{~mL})$ were analysed for hydrogen ion concentration by $\mathrm{pH}$-metric titration with $0.1 \mathrm{~N} \mathrm{NaOH}$ solution 
TABLE 1: Preliminary phytochemical analysis of the aqueous and $\mathrm{MeOH} / \mathrm{CH}_{2} \mathrm{CL}_{2}$ extracts, hexane, methylene chloride, ethyl acetate, and methanol fractions of E. speciosa.

\begin{tabular}{|c|c|c|c|c|c|c|}
\hline & Aqueous extract & $\mathrm{MeOH} / \mathrm{CH}_{2} \mathrm{CL}_{2}$ extract & Hexane fraction & $\mathrm{CH}_{2} \mathrm{CL}_{2}$ fraction & Ethyl acetate fraction & $\mathrm{MeOH}$ fraction \\
\hline Tannins & + & - & - & - & - & - \\
\hline Alkaloids & +++ & ++ & - & + & - & + \\
\hline Resins & ++ & - & - & - & - & - \\
\hline Saponins & - & - & - & - & - & - \\
\hline Flavonoids & +++ & +++ & ++ & ++ & + & + \\
\hline Anthocyanins & +++ & - & - & - & - & - \\
\hline Phenols & + & - & - & + & - & - \\
\hline Quinones & +++ & ++ & - & ++ & + & - \\
\hline Acids & - & + & + & + & + & - \\
\hline Sugars & - & - & - & - & - & - \\
\hline Oils & + & + & - & - & ++ & + \\
\hline Coumarins & - & + & - & - & - & + \\
\hline Sterols & + & ++ & + & ++ & ++ & - \\
\hline Triterpenoids & + & +++ & + & ++ & ++ & - \\
\hline Glycosides & + & ++ & ++ & ++ & + & - \\
\hline Amino acids & + & + & - & + & + & - \\
\hline Proteins & +++ & - & - & ++ & ++ & - \\
\hline
\end{tabular}

Strongly present: +++; present: ++; weakly present: +; absent: -.

using a digital $\mathrm{pH}$ meter. The acid content was expressed as $\mathrm{mEq} / \mathrm{L}$.

2.2.8. Mucus Production Assessment. The mucus covering of each stomach was gently scraped using a glass slide and the mucus weighed carefully using a sensitive digital electronic balance. The same experimenter performed this exercise each time.

2.2.9. Statistical Analysis. Results were analysed using the one-way ANOVA followed by the Student-Newman-Keuls posttest for comparison of treatment means. $P<0.05$ was considered significant. Values in tables are given as arithmetic means \pm standard error of the mean (S.E.M).

\section{Results}

Table 1 shows the phytochemical analysis of the aqueous and $\mathrm{MeOH} / \mathrm{CH}_{2} \mathrm{CL}_{2}$ extracts, hexane, methylene chloride, ethyl acetate, and methanol fractions of E. speciosa. The major classes of compounds present included alkaloids, flavonoids, triterpenoids, glycosides, anthocyanins, quinones, and proteins which were distributed in the different extracts and fractions.

Table 2 shows the results obtained after screening the crude extracts and the various fractions for antisecretory and cytoprotective effects. At the dose of $100 \mathrm{mg} / \mathrm{kg}$, only the crude $\mathrm{MeOH}-\mathrm{CH}_{2} \mathrm{Cl}_{2}$ and the $\mathrm{CH}_{2} \mathrm{Cl}_{2}$ fractions significantly reduced gastric acidity. When tested at the higher dose of $200 \mathrm{mg} / \mathrm{kg}$, they showed significant dose-dependent reductions in gastric acidity (51 and $45 \%$ reduction, resp.) compared with the aqueous extract (49\% reduction) at the same dose. Cimetidine $(50 \mathrm{mg} / \mathrm{kg})$ reduced gastric acidity by
58 percent. The low acid concentrations were accompanied by highly significant reductions $(P<0.001)$ in the volumes of gastric secretions, and significant cytoprotection was evident from the highly significant increases in mucus production compared with the controls. The $\mathrm{MeOH}-\mathrm{CH}_{2} \mathrm{Cl}_{2}$ extract, the $\mathrm{CH}_{2} \mathrm{Cl}_{2}$ fraction, and the aqueous extract were, thus, retained for the next set of experiments.

Tables 3 and 4 show the results obtained when, in addition to pylorus ligation, gastric hypersecretion was provoked by the administration of the secretagogues, histamine, and carbachol, respectively. Administration of histamine to the control animals raised gastric acidity to $86.50 \pm$ $2.98 \mathrm{mEq} / \mathrm{L}$ (Table 3) while carbachol-induced secretion was $84.80 \pm 3.57 \mathrm{mEq} / \mathrm{L}$ (Table 4$)$. Treatment with the extracts $(200 \mathrm{mg} / \mathrm{kg})$ and cimetidine $(100 \mathrm{mg} / \mathrm{kg})$ resulted in highly significant reductions in gastric acidity ranging from $34.60 \pm$ 3.33 to $59.00 \pm 4.08 \mathrm{mEq} / \mathrm{L}$ in the histamine-treated rats (Table 3) and from $39.00 \pm 5.34$ to $59.80 \pm 4.49 \mathrm{mEq} / \mathrm{L}$ in the carbachol-treated rats (Table 4 ). The extract-induced reductions in acid secretion were accompanied by highly significant reductions in volumes of gastric juice and ulcer indices and increases in mucus production both in the histamine- and carbachol-treated rats. Due to the similarity of the results between the extracts and the high presence of chlorophyll and the residual methanol in the $\mathrm{MeOH}-\mathrm{CH}_{2} \mathrm{Cl}_{2}$ extract and $\mathrm{CH}_{2} \mathrm{Cl}_{2}$ fraction, the aqueous extract was retained for further experimentation.

Intraduodenal administration of E. speciosa aqueous extract (200 and $400 \mathrm{mg} / \mathrm{kg}$ ) to pylorus ligated rats subjected to histamine-induced hypersecretion produced a highly significant $(P<0.001)$ dose-related decrease of acid secretion to $28.50 \pm 1.30 \mathrm{mEq} / \mathrm{L}$ and volume of gastric juice to $2.54 \pm$ $0.13 \mathrm{~mL}$ for the $400 \mathrm{mg} / \mathrm{kg}$ dose. $\mathrm{pH}$ values increased up to $4.83 \pm 0.11$ for the same dose. The high dose of aqueous extract 
TABLE 2: Effects of E. speciosa extracts and fractions on gastric acid secretion and ulceration in pylorus ligated rats.

\begin{tabular}{lccccccc}
\hline Treatment & $\begin{array}{c}\text { Dose } \\
(\mathrm{mg} / \mathrm{kg})\end{array}$ & Ulcer index & $\begin{array}{c}\% \\
\text { Inhibition }\end{array}$ & $\begin{array}{c}\text { Gastric mucus } \\
(\mathrm{mg})\end{array}$ & $\begin{array}{c}\text { Gastric juice } \\
(\mathrm{mL})\end{array}$ & $\begin{array}{c}\text { Gastric pH } \\
\text { Gastric acidity } \\
(\mathrm{mE} / \mathrm{L})\end{array}$ \\
\hline Control & - & $3.88 \pm 0.21$ & - & $45.04 \pm 5.09$ & $5.07 \pm 0.20$ & $2.66 \pm 0.15$ & $79.40 \pm 5.63$ \\
$\mathrm{CH}_{3} \mathrm{OH} / \mathrm{CH}_{2} \mathrm{CL}_{2}$ & 100 & $2.35 \pm 0.05$ & 39.43 & $78.20 \pm 3.53^{* * *}$ & $2.04 \pm 0.29^{* *}$ & $3.95 \pm 0.16^{* * *}$ & $46.00 \pm 6.33^{* *}$ \\
$\mathrm{CH}_{3} \mathrm{OH} / \mathrm{CH}_{2} \mathrm{CL}_{2}$ & 200 & $0.00 \pm 0.00^{* * *}$ & 100 & $98.47 \pm 3.67^{* * *}$ & $1.81 \pm 0.13^{* * *}$ & $4.01 \pm 0.17^{* * *}$ & $38.60 \pm 3.90^{* * *}$ \\
$\mathrm{CH}_{2} \mathrm{CL}_{2}$ fraction & 100 & $3.20 \pm 0.17$ & 17.53 & $51.13 \pm 2.95$ & $2.14 \pm 0.32^{* * *}$ & $3.54 \pm 0.19^{* *}$ & $55.60 \pm 6.57^{*}$ \\
$\mathrm{CH}_{2} \mathrm{CL}_{2}$ fraction & 200 & $1.30 \pm 0.37^{* * *}$ & 66.49 & $84.74 \pm 6.06^{* * *}$ & $1.96 \pm 0.10^{* * *}$ & $3.94 \pm 0.09^{* * *}$ & $43.20 \pm 3.65^{* * *}$ \\
Eth. Acet. fraction & 100 & $3.40 \pm 0.19$ & 12.37 & $60.70 \pm 2.83^{* *}$ & $5.30 \pm 0.26$ & $2.94 \pm 0.06$ & $71.60 \pm 4.06$ \\
Eth. Acet. fraction & 200 & $2.30 \pm 0.38^{*}$ & 40.72 & $65.90 \pm 2.33^{* *}$ & $4.93 \pm 0.36$ & $3.40 \pm 0.09$ & $59.70 \pm 3.58$ \\
Hexane fraction & 100 & $2.77 \pm 0.16^{*}$ & 28.60 & $70.72 \pm 2.73^{* * *}$ & $4.54 \pm 0.21$ & $3.45 \pm 0.24^{* *}$ & $64.20 \pm 6.91$ \\
Hexane fraction & 200 & $2.40 \pm 0.20$ & 38.14 & $79.89 \pm 3.89^{* * *}$ & $4.01 \pm 0.32$ & $3.52 \pm 0.39^{* *}$ & $54.90 \pm 5.92$ \\
$\mathrm{CH}_{3} \mathrm{OH}$ fraction & 100 & $3.43 \pm 0.16$ & 11.60 & $65.87 \pm 2.70^{* * *}$ & $5.16 \pm 0.21$ & $3.06 \pm 0.13$ & $67.00 \pm 6.12$ \\
$\mathrm{CH}_{3} \mathrm{OH}$ fraction & 200 & $2.90 \pm 0.19$ & 25.25 & $67.33 \pm 2.00^{* * *}$ & $5.01 \pm 0.19$ & $3.40 \pm 0.25^{* *}$ & $62.22 \pm 5.76^{*}$ \\
Aqueous extract & 100 & $1.46 \pm 0.06^{* * *}$ & 62.37 & $79.20 \pm 3.24^{* * *}$ & $4.70 \pm 0.30$ & $3.01 \pm 0.15^{* *}$ & $63.40 \pm 4.10^{*}$ \\
Aqueous extract & 200 & $1.00 \pm 0.27^{* * *}$ & 74.23 & $92.19 \pm 3.05^{* * *}$ & $2.10 \pm 0.17^{* * *}$ & $3.97 \pm 0.13^{* * *}$ & $40.02 \pm 2.56^{* * *}$ \\
Cimetidine & 50 & $1.60 \pm 0.43^{* * *}$ & 58.76 & $87.47 \pm 3.76^{* * *}$ & $2.06 \pm 0.28^{* * *}$ & $4.31 \pm 0.15^{* * *}$ & $33.40 \pm 4.32^{* * *}$ \\
\hline
\end{tabular}

$N=5$ rats per treatment; ${ }^{*} P<0.05$, statistically significant relative to control; ${ }^{* *} P<0.01$, statistically highly significant relative to control; ${ }^{* * *} P<0.001$, statistically very highly significant relative to control.

TABLE 3: Effects of orally administered E. speciosa on histamine-induced gastric ulcers and gastric secretion in rats.

\begin{tabular}{|c|c|c|c|c|c|c|c|}
\hline Treatment & $\begin{array}{c}\text { Dose } \\
(\mathrm{mg} / \mathrm{kg})\end{array}$ & $\begin{array}{c}\text { Ulcer index } \\
(\text { mean + SEM) }\end{array}$ & $\begin{array}{c}\% \\
\text { Inhibition }\end{array}$ & $\begin{array}{c}\text { Mucus } \\
\text { production }(\mathrm{mg}) \\
(\text { mean }+ \text { SEM })\end{array}$ & $\begin{array}{c}\text { Volume of gastric } \\
\text { juice }(\mathrm{mL}) \\
(\text { mean }+ \text { SEM })\end{array}$ & $\begin{array}{c}\text { Gastric pH } \\
(\text { mean + SEM })\end{array}$ & $\begin{array}{c}\text { Gastric acidity } \\
(\mathrm{mEq} / \mathrm{L}) \\
(\text { mean }+ \text { SEM })\end{array}$ \\
\hline Control & - & $4.12 \pm 0.16$ & - & $52.83 \pm 2.96$ & $6.87 \pm 0.31$ & $2.37 \pm 0.04$ & $86.50 \pm 2.98$ \\
\hline $\mathrm{CH}_{3} \mathrm{OH} / \mathrm{CH}_{2} \mathrm{Cl}_{2}$ & 200 & $0.00 \pm 0.00^{* * *}$ & 100.00 & $92.13 \pm 2.89^{* * *}$ & $3.07 \pm 0.18^{* * *}$ & $4.74 \pm 0.34^{* * *}$ & $39.50 \pm 3.19^{* * *}$ \\
\hline $\mathrm{CH}_{2} \mathrm{Cl}_{2}$ fraction & 200 & $1.57 \pm 0,65^{* * *}$ & 61.89 & $87.32 \pm 6.91^{* * *}$ & $3.32 \pm 0.38^{* * *}$ & $4.47 \pm 0.27^{* * *}$ & $49.80 \pm 4.14^{* * *}$ \\
\hline Aqueous extract & 200 & $1.90 \pm 0.29^{* * *}$ & 53.88 & $85.05 \pm 4.21^{* * *}$ & $3.50 \pm 0.45^{* * *}$ & $4.33 \pm 0.23^{* * *}$ & $59.00 \pm 4.08^{* * *}$ \\
\hline Cimetidine & 100 & $0.0 \pm 0.00^{* * *}$ & 100.00 & $88.8 \pm 3.62^{* * *}$ & $2.28 \pm 0.20^{* * *}$ & $4.96 \pm 0.24^{* * *}$ & $34.60 \pm 3.33^{* * *}$ \\
\hline
\end{tabular}

$N=5$ rats per treatment; ${ }^{*} P<0.05$, statistically significant relative to control; ${ }^{* *} P<0.01$, statistically highly significant relative to control; ${ }^{* * *} P<0.001$, statistically very highly significant relative to control.

also produced 100 percent inhibition of gastric ulceration and increased mucus production to $101.69 \pm 3.89 \mathrm{mg}$ compared with $56.36 \pm 3.35 \mathrm{mg}$ for the controls (Table 5). When the aqueous extract (200 and $400 \mathrm{mg} / \mathrm{kg}$ ) was administered intraduodenally to pylorus ligated rats treated with carbachol, similar dose-dependent reduction in gastric acid production to $28.80 \pm 1.30 \mathrm{mEq} / \mathrm{L}$ was obtained for the $400 \mathrm{mg} / \mathrm{kg}$ dose. Gastric juice $\mathrm{pH}$ increased to $5.26 \pm 0.12$ and volume of gastric juice reduced to $2.37 \pm 0.15$ for the same dose. Ulcer formation was totally inhibited and gastric mucus production increased significantly for the dose of $400 \mathrm{mg} / \mathrm{kg}$ (Table 6).

Repeated histamine injection to the control rats (augmented histamine test) further raised the basal gastric acid levels to $90.20 \pm 2.71 \mathrm{mEq} / \mathrm{L}$. Pretreatment with a single oral dose of aqueous extract (200 and $400 \mathrm{mg} / \mathrm{kg}$ ) prevented the histamine effect by reducing the acid secretion to values significantly below basal levels $(52.60 \pm 2.96$ and $27.50 \pm$ $1.29 \mathrm{mEq} / \mathrm{L}$, resp.). $\mathrm{pH}$ and volume of gastric juice at the dose of $400 \mathrm{mg} / \mathrm{kg}$ were $5.02 \pm 0.17$ and $2.06+0.18 \mathrm{~mL}$ compared to $2.29 \pm 0.06$ and $7.42 \pm 0.26 \mathrm{~mL}$, respectively, for the controls. There was complete inhibition of ulcer formation associated with significant increase in mucus production for cimetidine $(100 \mathrm{mg} / \mathrm{kg})$ and extract $(400 \mathrm{mg} / \mathrm{kg})$ (Table 7).

The effects of the extract when administered to carbachol/indomethacin-treated rats are shown in Table 8. Coadministration of carbachol and indomethacin significantly reduced the ulcer inhibition capacity of the oral aqueous extract $(200-400 \mathrm{mg} / \mathrm{kg})$ to $25-44 \%$ compared with 70-100\% inhibition (for carbachol alone, Table 4). This was accompanied by a drop in mucus production both for the controls and extract-treated rats. In addition, the volume of gastric juice $(3.96-5.09 \mathrm{~mL})$ and gastric acidity $(59.5 \pm$ $4.36-44.00 \pm 4.08 \mathrm{mEq} / \mathrm{L})$ remained high in response to the extract. When the extract was administered by duodenal route, the values of ulcer index, $\mathrm{pH}$, and volumes of gastric juice remained largely unchanged, and gastric acidity reduced significantly only for the $400 \mathrm{mg} / \mathrm{kg}$ dose (Table 9).

\section{Discussion}

In a preliminary study [39] we found that the water extract of E. speciosa had possible cytoprotective and antisecretory 
TABLE 4: Effects of orally administered E. speciosa on carbachol-induced gastric ulcers and gastric secretion in rats.

\begin{tabular}{lccccccc}
\hline Treatment & $\begin{array}{c}\text { Dose } \\
(\mathrm{mg} / \mathrm{kg})\end{array}$ & $\begin{array}{c}\text { Ulcer index } \\
(\text { mean }+ \text { SEM) }\end{array}$ & $\begin{array}{c}\% \\
\text { Inhibition }\end{array}$ & $\begin{array}{c}\text { Mucus } \\
\text { production }(\mathrm{mg}) \\
(\text { mean }+\mathrm{SEM})\end{array}$ & $\begin{array}{c}\text { Volume of gastric } \\
\text { juice }(\mathrm{mL}) \\
(\text { mean }+\mathrm{SEM})\end{array}$ & $\begin{array}{c}\text { Gastric pH } \\
(\mathrm{mean}+\mathrm{SEM})\end{array}$ & $\begin{array}{c}\text { Gastric acidity } \\
(\mathrm{mEq} / \mathrm{L}) \\
(\mathrm{mean}+\mathrm{SEM})\end{array}$ \\
\hline Control & - & $4.03 \pm 0.13$ & - & $49.34 \pm 3.20$ & $6.89 \pm 0.22$ & $2.59 \pm 0.04$ & $84.80 \pm 3.57$ \\
$\mathrm{CH}_{3} \mathrm{OH} / \mathrm{CH}_{2} \mathrm{Cl}_{2}$ & 200 & $1.43 \pm 0.37^{* * *}$ & 64.52 & $78.82 \pm 3.64^{* *}$ & $3.57 \pm 0.30^{* * *}$ & $4.35 \pm 0.12^{* * *}$ & $54.00 \pm 4.30^{* *}$ \\
$\mathrm{CH}_{2} \mathrm{Cl}_{2}$ fraction & 200 & $1.73 \pm 0.50^{* * *}$ & 57.07 & $76.08 \pm 2.83^{* *}$ & $3.71 \pm 0.25^{* * *}$ & $4.12 \pm 0.14^{* * *}$ & $59.80 \pm 4.49^{* *}$ \\
Aqueous extract & 200 & $1.20 \pm 0.34^{* * *}$ & 70.22 & $79.19 \pm 3.66^{* *}$ & $3.99 \pm 0.27^{* * *}$ & $4.24 \pm 0.22^{* * *}$ & $50.00 \pm 4.26^{* * *}$ \\
Cimetidine & 50 & $1.10 \pm 0.46^{* * *}$ & 72.71 & $69.42 \pm 3.42^{*}$ & $2.76 \pm 0.37^{* * *}$ & $5.48 \pm 0.17^{* * *}$ & $39.00 \pm 5.34^{* * *}$ \\
\hline
\end{tabular}

$N=5$ rats per treatment; ${ }^{*} P<0.05$, statistically significant relative to control; ${ }^{* *} P<0.01$, statistically highly significant relative to control; ${ }^{* * *} P<0.001$, statistically very highly significant relative to control.

TABLE 5: Effects of duodenally administered aqueous extract of E. speciosa on gastric ulceration and secretion induced by histamine in rats.

\begin{tabular}{|c|c|c|c|c|c|c|c|}
\hline Treatment & $\begin{array}{c}\text { Dose } \\
(\mathrm{mg} / \mathrm{kg})\end{array}$ & $\begin{array}{c}\text { Ulcer index } \\
(\text { mean + SEM })\end{array}$ & $\begin{array}{c}\% \\
\text { Inhibition }\end{array}$ & $\begin{array}{c}\text { Mucus } \\
\text { production }(\mathrm{mg}) \\
(\text { mean }+ \text { SEM })\end{array}$ & $\begin{array}{c}\text { Volume of gastric } \\
\text { juice }(\mathrm{mL}) \\
(\text { mean }+ \text { SEM })\end{array}$ & $\begin{array}{c}\text { Gastric pH } \\
(\text { mean + SEM })\end{array}$ & $\begin{array}{c}\text { Gastric acidity } \\
(\mathrm{mEq} / \mathrm{L}) \\
(\text { mean }+\mathrm{SEM})\end{array}$ \\
\hline Control & - & 4.07 & - & $59.06 \pm 2.30$ & $6.64 \pm 0.24$ & 2.25 & 3.56 \\
\hline E. speciosa & 200 & $2.40 \pm 0.19^{* * *}$ & 41.03 & $84.82 \pm 2.69^{* * *}$ & $4.54 \pm 0.21^{* * *}$ & $3.99 \pm 0.16^{* * *}$ & $54.60 \pm 2.70^{* * *}$ \\
\hline E. speciosa & 400 & $0.00 \pm 0.00^{* * *}$ & 100.00 & $101.69 \pm 3.89^{* * *}$ & $2.54 \pm 0.13^{* * *}$ & $4.65 \pm 0.10^{* * *}$ & $28.50 \pm 1.30^{* * *}$ \\
\hline Ranitidine & 100 & $1.91 \pm 0.33^{* * *}$ & 53.00 & $89.87 \pm 2.01^{* * *}$ & $2.02 \pm 0.15^{* * *}$ & $5.02 \pm 0.17^{* * *}$ & $36.36 \pm 1.46^{* * *}$ \\
\hline
\end{tabular}

$N=5$ rats per treatment; ${ }^{* * *} P<0.001$; statistically very highly significant relative to control.

TABLE 6: Effects of duodenally administered aqueous extract of E. speciosa on gastric ulceration and secretion induced by carbachol in rats.

\begin{tabular}{lccccccc}
\hline Treatment & $\begin{array}{c}\text { Dose } \\
(\mathrm{mg} / \mathrm{kg})\end{array}$ & $\begin{array}{c}\text { Ulcer index } \\
(\text { mean + SEM) }\end{array}$ & $\begin{array}{c}\% \\
\text { Inhibition }\end{array}$ & $\begin{array}{c}\text { Mucus } \\
\text { production }(\mathrm{mg}) \\
(\text { mean + SEM) }\end{array}$ & $\begin{array}{c}\text { Volume of gastric } \\
\text { juice }(\mathrm{mL}) \\
(\text { mean }+ \text { SEM) }\end{array}$ & $\begin{array}{c}\text { Gastric pH } \\
(\mathrm{mean}+\mathrm{SEM})\end{array}$ & $\begin{array}{c}\text { Gastric acidity } \\
(\mathrm{mEq} / \mathrm{L}) \\
(\mathrm{mean}+\mathrm{SEM})\end{array}$ \\
\hline Control & - & $3.90 \pm 0.19$ & - & $56.36 \pm 3.35$ & $6.71 \pm 0.19$ & $2.72 \pm 0.07$ \\
E. speciosa & 200 & $2.02 \pm 0.20^{* * *}$ & 48.21 & $77.60 \pm 2.78^{* * *}$ & $3.97 \pm 0.25^{* * *}$ & $4.15 \pm 0.12^{* * *}$ & $51.40 \pm 3.97^{* * *}$ \\
E. speciosa & 400 & $0.00 \pm 0.00^{* * *}$ & 100.00 & $103.20 \pm 3.19^{* * *}$ & $2.37 \pm 0.15^{* * *}$ & $5.26 \pm 0.12^{* * *}$ & $28.80 \pm 1.38^{* * *}$ \\
Ranitidine & 100 & $1.76 \pm 0.23^{* * *}$ & 55.00 & $82.34 \pm 3.48^{* * *}$ & $2.48 \pm 0.19^{* * *}$ & $4.96 \pm 0.28^{* * *}$ & $34.20 \pm 1.42^{* * *}$ \\
\hline
\end{tabular}

$N=5$ rats per treatment; ${ }^{* * *} P<0.001$; statistically very highly significant relative to control.

TABLE 7: Effects of orally administered aqueous extract of E. speciosa on gastric ulceration and secretion in rats submitted to the augmented histamine test.

\begin{tabular}{|c|c|c|c|c|c|c|c|}
\hline Treatment & $\begin{array}{c}\text { Dose } \\
(\mathrm{mg} / \mathrm{kg})\end{array}$ & $\begin{array}{c}\text { Ulcer index } \\
(\text { mean + SEM })\end{array}$ & $\begin{array}{c}\% \\
\text { Inhibition }\end{array}$ & $\begin{array}{c}\text { Mucus } \\
\text { production }(\mathrm{mg}) \\
(\text { mean }+ \text { SEM })\end{array}$ & $\begin{array}{c}\text { Volume of gastric } \\
\text { juice }(\mathrm{mL}) \\
(\text { mean }+ \text { SEM })\end{array}$ & $\begin{array}{c}\text { Gastric pH } \\
(\text { mean + SEM })\end{array}$ & $\begin{array}{c}\text { Gastric acidity } \\
(\mathrm{mEq} / \mathrm{L}) \\
(\text { mean }+\mathrm{SEM}) \\
\end{array}$ \\
\hline Control & - & & - & $52.84 \pm 2.42$ & $7.42 \pm 0.26$ & & $90.20 \pm 2.71$ \\
\hline E. speciosa & 200 & $2.27 \pm 0.19^{* * *}$ & 47.58 & $82.20 \pm 2.82^{* * *}$ & $3.76 \pm 0.26^{* * *}$ & $3.99 \pm 0.16^{* * *}$ & $52.60 \pm 2.96^{* * *}$ \\
\hline E. speciosa & 400 & $0.00 \pm 0.0^{* * *}$ & 100.00 & $96.51 \pm 3.12^{* * *}$ & $2.20 \pm 0.27^{* * *}$ & $4.65 \pm 0.10^{* * *}$ & $27.50 \pm 1.29^{* * *}$ \\
\hline Ranitidine & 100 & $0.00 \pm 0.00^{* * *}$ & 100.00 & $73.21 \pm 2.43^{* * *}$ & $2.06 \pm 0.18^{* * *}$ & $5.02 \pm 0.17^{* * *}$ & $19.20 \pm 1.68^{* * *}$ \\
\hline
\end{tabular}

$N=5$ rats per treatment; ${ }^{* * *} P<0.001$; statistically very highly significant relative to control.

TABLE 8: Effects of orally administered aqueous extract of E. speciosa on gastric ulceration and secretion in pylorus-ligated rats treated with indomethacin/carbachol.

\begin{tabular}{|c|c|c|c|c|c|c|c|}
\hline Treatment & $\begin{array}{c}\text { Dose } \\
(\mathrm{mg} / \mathrm{kg})\end{array}$ & $\begin{array}{c}\text { Ulcer index } \\
(\text { mean + SEM })\end{array}$ & $\begin{array}{c}\% \\
\text { Inhibition }\end{array}$ & $\begin{array}{c}\text { Mucus } \\
\text { production }(\mathrm{mg}) \\
(\text { mean }+ \text { SEM })\end{array}$ & $\begin{array}{c}\text { Volume of gastric } \\
\text { juice }(\mathrm{mL}) \\
(\text { mean }+ \text { SEM })\end{array}$ & $\begin{array}{c}\text { Gastric pH } \\
(\text { mean + SEM })\end{array}$ & $\begin{array}{c}\text { Gastric acidity } \\
(\mathrm{mEq} / \mathrm{L}) \\
(\text { mean }+\mathrm{SEM})\end{array}$ \\
\hline Control & - & $4.13 \pm 0.21$ & - & $38.87 \pm 4.59$ & $7.32 \pm 0.26$ & $2.64 \pm 0.15$ & $92.10 \pm 4.39$ \\
\hline E. speciosa & 200 & $3.10 \pm 0.25^{* *}$ & 24.94 & $60.63 \pm 5.67^{*}$ & $5.14 \pm 0.29^{* * *}$ & $3.96 \pm 0.08^{* * *}$ & $59.50 \pm 4.36^{* * *}$ \\
\hline E. speciosa & 400 & $2.31 \pm 0.13^{* * *}$ & 44.07 & $74.01 \pm 6.90^{* *}$ & $4.16 \pm 0.31^{* * *}$ & $4.77 \pm 0.07^{* * *}$ & $44.00 \pm 4.08^{* * *}$ \\
\hline Ranitidine & 100 & $2.03 \pm 0.20^{* * *}$ & 50.85 & $49.02 \pm 5.31$ & $3.64 \pm 0.30^{* * *}$ & $5.09 \pm 0.25^{* * *}$ & $35.05 \pm 3.03^{* * *}$ \\
\hline
\end{tabular}

$N=5$ rats per treatment; ${ }^{*} P<0.05$, statistically significant relative to control; ${ }^{* *} P<0.01$, statistically highly significant relative to control; ${ }^{* * *} P<0.001$, statistically very highly significant relative to control. 
TABLE 9: Effects of duodenally administered aqueous extract of E. speciosa on gastric ulceration and secretion in pylorus-ligated rats treated with indomethacin/carbachol.

\begin{tabular}{|c|c|c|c|c|c|c|c|}
\hline Treatment & $\begin{array}{c}\text { Dose } \\
(\mathrm{mg} / \mathrm{kg})\end{array}$ & $\begin{array}{c}\text { Ulcer index } \\
(\text { mean + SEM })\end{array}$ & $\begin{array}{c}\% \\
\text { Inhibition }\end{array}$ & $\begin{array}{c}\text { Mucus } \\
\text { production }(\mathrm{mg}) \\
(\text { mean }+ \text { SEM })\end{array}$ & $\begin{array}{c}\text { Volume of gastric } \\
\text { juice }(\mathrm{mL}) \\
(\text { mean + SEM })\end{array}$ & $\begin{array}{c}\text { Gastric pH } \\
(\text { mean + SEM })\end{array}$ & $\begin{array}{c}\text { Gastric acidity } \\
(\mathrm{mEq} / \mathrm{L}) \\
(\text { mean }+\mathrm{SEM})\end{array}$ \\
\hline Control & - & $3.80 \pm 0.13$ & - & $44.39 \pm 4.82$ & $6.91 \pm 0.15$ & $2.72 \pm 0.11$ & $88.50 \pm 5.10$ \\
\hline E. speciosa & 200 & $2.68 \pm 0.23^{* * *}$ & 29.47 & $59.43 \pm 4.45$ & $5.02 \pm 0.42^{* * *}$ & $4.02 \pm 0.12^{* * *}$ & $60.50 \pm 4.36^{* * *}$ \\
\hline E. speciosa & 400 & $2.40 \pm 0.10^{* * *}$ & 36.84 & $66.73 \pm 5.44^{*}$ & $4.48 \pm 0.25^{* * *}$ & $4.60 \pm 0.15^{* * *}$ & $34.50 \pm 3.57^{* * *}$ \\
\hline Ranitidine & 100 & $2.03 \pm 0.20^{* * *}$ & 50.85 & $49.02 \pm 5.31$ & $3.64 \pm 0.30^{* * *}$ & $5.09 \pm 0.25^{* * *}$ & $35.05 \pm 3.03^{* * *}$ \\
\hline
\end{tabular}

$N=5$ rats per treatment; ${ }^{*} P<0.05$, statistically significant relative to control; ${ }^{* * *} P<0.001$, statistically very highly significant relative to control.

effects but no study has been carried out to explore the possible mechanism of action. In the present study, several extracts and unpurified fractions were screened for comparative antisecretory effects. The $\mathrm{MeOH}-\mathrm{CH}_{2} \mathrm{Cl}_{2}$ and aqueous extracts and the $\mathrm{CH}_{2} \mathrm{Cl}_{2}$ fraction showed significant antisecretory activity at the lower dose of $100 \mathrm{mg} / \mathrm{kg}$ and significant dosedependent activity at $200 \mathrm{mg} / \mathrm{kg}$ and were further screened for their response to secretagogue-induced gastric acid secretion. The three products $(200 \mathrm{mg} / \mathrm{kg})$ showed highly significant reductions in acid secretion induced by histamine (31$54 \%)$ and carbachol (29-41\%). However, the $\mathrm{MeOH}-\mathrm{CH}_{2} \mathrm{Cl}_{2}$ extract had higher antisecretory activity against histamineinduced secretion, while the aqueous extract showed higher antisecretory effects against carbachol-induced gastric acid secretion.

The pylorus ligation technique usually causes accumulation of gastric acid in the stomach and agents that reduce acid secretion and/or increase mucus secretion are effective in inhibiting ulcer formation by this method. The accumulated acid, in addition to its corrosive action on gastric glandular epithelium, provides the optimum $\mathrm{pH}$ (1.63.2) for the conversion of pepsinogen to pepsin. Both $\mathrm{HCl}$ and pepsin are important ingredients for the formation of pylorus ligated ulcers [42]. The $\mathrm{MeOH}-\mathrm{CH}_{2} \mathrm{Cl}_{2}$ and aqueous extracts and the $\mathrm{CH}_{2} \mathrm{Cl}_{2}$ fraction significantly reduced the volume and acidity of gastric secretions and increased $\mathrm{pH}$ of gastric juice compared with the controls. This, in addition to the significant increases in gastric mucus production, contributed to the significant inhibition of gastric ulceration (Table 2). In Shay ligated rats, gastric acid levels of $40 \mathrm{mEq} / \mathrm{L}$ and above have been associated with severe ulceration of the rat gastric mucosa $[39,43,44]$. In the present study, the extracts reduced gastric acidity from $79.4 \mathrm{mEq} / \mathrm{L}$ in the controls down to between 38.6 and $40.2 \mathrm{mEq} / \mathrm{L}$, while inhibition of ulcer formation ranged between 74 and $100 \%$. These results underline the protective role of the increased gastric mucus secretion in extract-treated rats (92.19-98.47 g) compared with the controls (45.04 g) (Table 1). Pepsin inactivation occurs at about $\mathrm{pH} 6$. Between $\mathrm{pH} 4$ and 6, pepsin is still stable but inactive [45]. Gastric $\mathrm{pH}$ values obtained in all the experiments in response to extract administration ranged between 3.97 and 5.26, suggesting that the extract may deactivate gastric pepsin and interfere with protein digestion.

Neural, endocrine, and paracrine systems are responsible for the physiological control of gastric secretion. Acetylcholine and histamine directly activate acid secretion but by different pathways. While acetylcholine binds to $\mathrm{M}_{3}$ muscarinic receptors causing an increase in parietal cell intracellular calcium, histamine binds to $\mathrm{H}_{2}$-receptors and provokes an elevation of both intracellular calcium and of cyclic AMP. Cimetidine, which is a well-known $\mathrm{H}_{2}$-receptor antagonist, inhibits the activation of adenyl cyclase, thus, blocking the formation of cyclic AMP that is necessary for $\mathrm{HCl}$ production. Carbachol is a cholinomimetic drug which, like acetylcholine, increases free intracellular calcium. The resulting activation of protein kinase by phosphorylation leads to increased $\mathrm{HCl}$ production. Degranulation of peritoneal mast cells to release histamine is critically dependent on extracellular calcium concentration. Agents like verapamil and ranitidine, that block T-type low voltage-sensitive calcium channel opening and calcium influx through interference with $\mathrm{H}^{+} \mathrm{K}^{+}$ATPase from the luminal side of the stomach, reduce both the volume and acidity of gastric secretions [46-50]. Calcium channel blockers exert their inhibitory effects on histamine, gastrin, carbachol, and cyclic AMP-induced stimulation of gastric acid secretion [51].

In our study, the $\mathrm{CH}_{2} \mathrm{Cl}_{2}$ fraction, the $\mathrm{MeOH}-\mathrm{CH}_{2} \mathrm{Cl}_{2}$ and aqueous extracts $(200 \mathrm{mg} / \mathrm{kg})$, and cimetidine significantly raised gastric $\mathrm{pH}$ and reduced the volume and secretion of gastric acid in both histamine- and carbachol-treated rats. Further experimentation with the aqueous extract (200-400 mg/kg) yielded highly significant dose-dependent reduction of volume and acidity of gastric secretion when the extract was administered by intraduodenal route. These results suggest that the observed reductions in gastric acidity could be due to an $\mathrm{H}_{2}$-receptor blocking mechanism similar to cimetidine as well as M-3 muscarinic receptor blocking activity similar to verapamil. Since carbachol- and histamineactivated acid secretions occur by separate mechanisms, the extract of E. speciosa may contain two or more antisecretory ingredients acting separately and synergistically. This may, therefore, explain the highly significant acid reduction observed in the secretagogue-treated rats. It is worth noting that even in histamine-treated rats, the laparotomy- and pylorus ligation-induced pain constitutes a source of stress which contributes to acid secretion through the cholinergic pathway. When histaminergic and cholinergic stimulations of gastric acid secretion were similarly reduced by the aqueous extract of Stachytarpheta cayennensis, it was suggested [40] that the extract could be acting through the inhibition of common steps in both pathways, possibly at the level of histamine release $/ \mathrm{H}_{2}$-receptor interaction or at the proton 
pump. In addition, the effects of E. speciosa aqueous extract may not be attributed to a gastric luminal topical activity alone since the extract was also active when administered by intraduodenal route. The striking similarity in acid reduction capacity when the aqueous extract $(200 \mathrm{mg} / \mathrm{kg})$ was administered by oral and duodenal route both for histamine- $(59.00 \pm$ 4.08 and $54.62 \pm 2.70 \mathrm{mEq} / \mathrm{L}$, resp.) and carbachol- (50.00 \pm 4.26 and $51.40 \pm 3.97 \mathrm{mEq} / \mathrm{L}$, resp.) induced secretion is suggestive of the involvement of an active secondary metabolite.

The antiulcerogenic and antisecretory effects of $E$. speciosa aqueous extract dropped when carbachol was coadministered with indomethacin. Indomethacin, an NSAID, is well-known for its ability to suppress prostaglandin synthesis, bicarbonate secretion, and gastric mucosal blood flow in animals [52-54]. These effects increase gastric mucosal susceptibility to injury and exacerbate, in synergy with carbachol, the ulcerogenic effects of increased acid, and pepsin secretion in the stomach $[41,55]$. The vital role that prostaglandins play in gastric mucosal protection is wellknown. When the cytoprotective effect of an antiulcer agent is significantly reduced by pretreatment with indomethacin, it is usually interpreted that the cytoprotection is mediated by endogenous prostaglandins.

In the present study, histamine-induced basal acid secretion was higher $(86.5-88.3 \mathrm{mEq} / \mathrm{L})$ compared to carbacholinduced basal secretions (84.5-85.2 $\mathrm{mEq} / \mathrm{L})$, and histamineinduced basal secretion rose to $90.2 \mathrm{mEq} / \mathrm{L}$ in the augmented histamine test. These results are in agreement with previous findings [55] which showed that carbachol-induced secretion by parietal cells is fast, small, and transient, whereas histamine-provoked secretion is slow, large, and sustained. The large sustained secretion induced by the augmented histamine test $(90.20 \pm 2.71 \mathrm{mEq} / \mathrm{L})$ was reduced to very low levels by $400 \mathrm{mg} / \mathrm{kg}$ of E. speciosa aqueous extract $(27.50 \pm 1.29 \mathrm{mEq} / \mathrm{L})$ and by $100 \mathrm{mg} / \mathrm{kg}$ of cimetidine $(19.2 \pm$ $1.68 \mathrm{mEq} / \mathrm{L})$. Similar levels of gastric acidity $(25 \mathrm{mEq} / \mathrm{L})$ have previously been observed [39] not to cause gastric mucosal ulceration in pylorus ligated rats. Our results are similar to findings that cimetidine significantly reduces both the volume and acidity of gastric secretions. They also demonstrate the strong antisecretory and antiulcer actions of $E$. speciosa aqueous extract at $400 \mathrm{mg} / \mathrm{kg}$ similar to Myristica fragrans [56] and Hibiscus rosasinensis [7] aqueous extracts (500 mg/kg) against secretagogue-induced hyperacidity. Phytochemical screening of the extracts and fractions (Table 1) showed the predominant presence of alkaloids, triterpenes, flavonoids, and phenols which are well-known for their gastric antisecretory and cytoprotective activities [17-20].

\section{Conclusion}

In conclusion, the water and $\mathrm{MeOH}-\mathrm{CH}_{2} \mathrm{Cl}_{2}$ extracts and the $\mathrm{CH}_{2} \mathrm{Cl}_{2}$ fraction of $\mathrm{E}$. speciosa protected the rat gastric mucosa and inhibited gastric acid secretion. In addition to increased mucus production, the aqueous extract offers cytoprotection through a mechanism that involves the physicochemical reenforcement of the gastric mucous layer or by effects similar to endogenous prostaglandins. The antisecretory effect of the aqueous extract may involve a mechanism common to both cholinergic and histaminergic pathways. This may be attributed to the various bioactive compounds present in the extract. The results lend credence to the wide traditional use of E. speciosa in the management of complaints symptomatic of peptic ulcer disease.

\section{Conflict of Interests}

The authors declare that there is no conflict of interests regarding the publication of this paper.

\section{References}

[1] M. I. Grossman, Ed., Peptic Ulcer: A Guide for the Practicing Physician, Year book Medical, Chicago, Ill, USA, 1981.

[2] C. R. W. Edward, I. A. D. Bouchier, and C. Haslett, "Diseases of the stomach," in Davison's Principles and Practice of Medicine, pp. 425-434, Churchill Livingstone, London, UK, 1995.

[3] B. J. Marshall and J. R. Warren, "Unidentified curved bacilli in the stomach of patients with gastritis and peptic ulceration," The Lancet, vol. 1, no. 8390, pp. 1311-1314, 1984.

[4] J. W. Black, W. A. M. Duncan, C. J. Durant, C. R. Ganellin, and E. M. Parsons, "Definition and antagonism of histamine H2receptors," Nature, vol. 236, no. 5347, pp. 385-390, 1972.

[5] E. Fellenius, T. Berglindh, and G. Sachs, "Substituted benzimidazoles inhibit gastric acid secretion by blocking $(\mathrm{H}++$ K+)ATPase," Nature, vol. 290, no. 5802, pp. 159-161, 1981.

[6] J. M. Wolosin and J. G. Forte, "Stimulation of oxyntic cell triggers $\mathrm{K}+$ and $\mathrm{Cl}-$ conductances in apical $\mathrm{H}+-\mathrm{K}+-$ ATPase membrane," American Journal of Physiology, vol. 15, no. 3, pp. C537-C545, 1984.

[7] M. F. Dixon, R. M. Genta, J. H. Yardley et al., "Classification and grading of Gastritis: the updated Sydney system," American Journal of Surgical Pathology, vol. 20, no. 10, pp. 1161-1181, 1996.

[8] K. E. L. McColl, E. El-Omar, and D. Gillen, "Interactions between Helicobacter pylori infection, gastric acid secretion and anti-secretory therapy," British Medical Bulletin, vol. 54, no. 1, pp. 121-138, 1998.

[9] K. A. Ryan, L.-J. Van Doorn, A. P. Moran, M. Glennon, T. Smith, and M. Maher, "Evaluation of clarithromycin resistance and cagA and vacA genotyping of Helicobacter pylori strains from the west of Ireland using line probe assays," Journal of Clinical Microbiology, vol. 39, no. 5, pp. 1978-1980, 2001.

[10] I. L. P. Beales, "Efficacy of Helicobacter pylori eradication therapies: a single centre observational study," BMC Gastroenterology, vol. 1, article 7, 2001.

[11] S. Suerbaum and P. Michetti, "Helicobacter pylori infection," The New England Journal of Medicine, vol. 347, no. 15, pp. 1175-1186, 2002.

[12] M. B. Skirrow, "Campylobacter and helicobacter; enteritis; gastritis," in Medical Microbiology, D. Greenwood et al., Ed., pp. 353-361, Churchill Livingstone, 14th edition, 1992.

[13] J. L. Fauchere, "Bacteriological characteristics and diagnosis of Helicobacter pylori," Laborama, vol. 6, pp. 10-14, 1999.

[14] M. Kato, Y. Yamaoka, J. J. Kim et al., "Regional differences in metronidazole resistance and increasing clarithromycin resistance among Helicobacter pylori, isolates from Japan," Antimicrobial Agents and Chemotherapy, vol. 44, no. 8, pp. 2214-2216, 2000 . 
[15] T. Okamoto, H. Yoshiyama, T. Nakazawa et al., "A change in PBP1 is involved in amoxicillin resistance of clinical isolates of Helicobacter pylori," Journal of Antimicrobial Chemotherapy, vol. 50, no. 6, pp. 849-856, 2002.

[16] M. L. Schubert and D. A. Peura, "Control of gastric acid secretion in health and disease," Gastroenterology, vol. 134, no. 7, pp. 1842-1860, 2008.

[17] A. Favier, "Le stress oxydant: intérêt conceptuel et expérimental dans la compréhension des mécanismes des maladies et potentiel thérapeutique. Dans: Mécanismes Biochimiques," L'Actualité Chimique, pp. 108-115, 2003.

[18] M. B. Gupta, R. Nath, G. P. Gupta, and K. P. Bhargava, "Antiulcer activity of some plant triterpenoids," Indian Journal of Medical Research, vol. 73, no. 4, pp. 649-652, 1981.

[19] P. V. Tan and B. Nyasse, "Anti-ulcer compound from Voacanga africana with possible histamine $\mathrm{H}_{2}$ receptor blocking activity," Phytomedicine, vol. 7, no. 6, pp. 509-515, 2000.

[20] P. V. Tan, B. Nyasse, G. E. Enow-Orock, P. Wafo, and E. A. Forcha, "Prophylactic and healing properties of a new anti-ulcer compound from Enantia chlorantha in rats," Phytomedicine, vol. 7, no. 4, pp. 291-296, 2000.

[21] O. E. Mboso, E. U. Eyong, M. O. Odey, and E. Osakwe, "Comparative phytochemical screening of Ereromastax speciosa and Ereromastax polysperma," Journal of Natural Product and Plant Resources, no. 2, pp. 37-41, 2013.

[22] F. Borrelli and A. A. Izzo, "The plant kingdom as a source of anti-ulcer remedies," Phytotherapy Research, vol. 14, pp. 581-591, 2000.

[23] H. Heine, “Acanthacees," in Flore Du Gabon, vol. 3, pp. 29-32, Museum Nationale d'Histoire Naturelle, Paris, France, 1966.

[24] J. E. Oben, S. E. Assi, G. A. Agbor, and D. F. Musoro, "Effect of Eremomastax speciosa on experimental diarrhoea," African Journal of Traditional, Complementary and Alternative Medicines, vol. 3, no. 1, pp. 95-100, 2006.

[25] J. O. Erhabor, M. Idu, and F. O. Udo, "Ethnomedicinal survey of medicinal plants used in the treatment of male infertilty among the IFA Nkari People of Ini Local Government area of Akwa Ibom State, Nigeria," Research Journal of Recent Sciences, vol. 2, pp. 5-11, 2013.

[26] J. E. Okokon, B. S. Antia, A. E. Udoh, and M. M. Akpan, "Antianaemic and antimicrobial activity of Eremomastax speciosa," Journal of Pharmacology and Toxicology, vol. 2, pp. 196-199, 2007.

[27] S. D. Dibong, M. E. Mpondo, A. Ngoye, and R. J. Priso, "Modalities of exploitation of medicinal plants in Douala's region," American Journal of Food and Nutrition, vol. 1, no. 2, pp. 67-73, 2011.

[28] P. B. Telefo, M. C. Lemfack, B. Bayala et al., "Ethnopharmacological survey of medicinal plants used in women infertility treatment in Fossong-Wentcheng and Foto villages, Western Region of Cameroon," Phytotherapie, vol. 10, no. 1, pp. 25-34, 2012.

[29] D. A. Focho, W. T. Ndam, and B. A. Fonge, "Medicinal plants of Aguambu-Bamumbu in the Lebialem highlands, southwest province of Cameroon," African Journal of Pharmacy and Pharmacology, vol. 3, no. 1, pp. 001-013, 2009.

[30] E. N. Ndenecho, "Herbalism and resources for the development of ethnopharmacology in Mount Cameroon region," African Journal of Pharmacy and Pharmacology, vol. 3, no. 3, pp. 078086, 2009.
[31] P. V. Tan, N. G. Nditafon, M. P. Yewah, T. Dimo, and F. J. Ayafor, "Eremomastax speciosa: effects of leaf aqueous extract on ulcer formation and gastric secretion in rats," Journal of Ethnopharmacology, vol. 54, no. 2-3, pp. 139-142, 1996.

[32] P. A. Amang, P. V. Tan, S. A. Patamaken, and M. N. Mefe, "Cytoprotective and antioxidant effects of the methanol extract of Eremomastax speciosa in rats," African Journal of Traditional, Complementary and Alternative Medicines, vol. 11, no. 1, pp. 165171,2014

[33] O. O. Odebiyi and E. A. Sofowora, "Phytochemical screening of Nigerian medicinal plants II," Lloydia, vol. 41, no. 3, pp. 234246, 1978.

[34] J. B. Harbone, Phytochemical Methods. A Guide to Modern Techniques of Plant Analysis, Chapman and Hall, London, UK, 1976.

[35] C. V. Schoppe, Chemistry of the Steroids, Butterworth, London, UK, 2nd edition, 1964.

[36] M. E. Wall, C. R. Eddy, M. L. McClennan, and M. E. Klumpp, "Detection and estimation of steroidal sapogenins in plant tissue," Analytical Chemistry, vol. 24, no. 8, pp. 1337-1341, 1952.

[37] G. E. Trease and W. C. Evans, A Textbook of Pharmacognosy, Bailliere Tindall, London, UK, 13th edition, 1989.

[38] E. E. Kovac-Besovi and K. Duri, “Thin layer Chromatographyapplication in qualitative analysis on presence of coumarins and flavonoids in plant material," Bosnian Journal of Basic Medical Sciences, vol. 3, no. 3, pp. 19-26, 2003.

[39] S. M. Vela, C. Souccar, M. T. R. Lima-Landman, and A. J. Lapa, "Inhibition of gastric acid secretion by the aqueous extract and purified extracts of Stachytarpheta cayennensis," Planta Medica, vol. 63, no. 1, pp. 36-39, 1997.

[40] K. D. Rainsford, "Gastric ulcerogenicity of non-steroidal antiinflamatory drugs in mice with mucosa sensitized by cholinomimetic treatment," Biochemical Pharmacology, vol. 27, pp. 1281-1289, 1978.

[41] J. P. Shay, S. A. Komarov, S. S. Fels, D. Meranze, M. Grunstein, and H. Simpler, "A simple method for the uniform production of gastric ulceration in the rat," Gastroenterology, vol. 5, pp. 4361, 1945.

[42] M. J. Martin, E. Marhuenda, C. Perez-Guerrero, and J. M. Franco, "Antiulcer effect of naringin on gastric lesions induced by ethanol in rats," Pharmacology, vol. 49, no. 3, pp. 144-150, 1994.

[43] E. Marhuenda, M. J. Martin, and C. Alarcon De La Lastra, "Antiulcerogenic activity of aescine in different experimental models," Phytotherapy Research, vol. 7, no. 1, pp. 13-16, 1993.

[44] J. Vatier and T. Vallot, "Antacides," in Pharmacologie. Des Concceptes Fondamentaux Aux Applications Therapeutiques, pp. 555-565, Frison-Roche, Paris, France, 1998.

[45] J. F. Perez-Zoghbi, A. Mayora, M. C. Ruiz, and F. Michelangeli, "Heterogeneity of acid secretion induced by carbachol and histamine along the gastric gland axis and its relationship to $\left[\mathrm{Ca}^{2+}\right]_{i}$," American Journal of Physiology, vol. 295, no. 4, pp. G671-G681, 2008.

[46] R. J. Mandade, S. A. Sreenivas, D. M. Sakarkar, and A. Choudhury, "Pharmacological effects of aqueous-ethanolic extract of Hibiscus rosasinensis on volume and acidity of stimulated gastric secretion," Asian Pacific Journal of Tropical Medicine, vol. 4, no. 11, pp. 883-888, 2011.

[47] P. A. Negulescu and T. E. Matchen, "Intracelluar calcium regulation during secretagogue stimulation of the parietal cells," American Journal of Physiology, vol. 254, pp. 130-138, 1998. 
[48] R. Brage, J. Cortjio, and J. Esplugues, "Effects of calcium channel blockers on gastric emptying and acid secretion of the rat in vivo," British Journal of Pharmacology, vol. 89, no. 4, pp. 627633, 1986.

[49] B. Kadalmani, M. Saravana Kumar, P. Revathi, and K. Prakash Shyam, "Gastric ulcer protective property of calcium channel Blockers in male albino rats," International Journal of Pharma and Bio Sciences, vol. 2, no. 1, pp. 629-636, 2011.

[50] K. F. Sewing and H. Hannemann, "Calcium channel antagonists verapamil and gallopamil are powerful inhibitors of acid secretion in isolated and enriched guinea pig parietal cells," Pharmacology, vol. 27, no. 1, pp. 9-14, 1983.

[51] G. Flemstrom, A. Garner, and O. Nylander, "Surface epithelial $\mathrm{HCO}_{3}$ transport by mammalian duodenum in vivo," American Journal of Physiology, vol. 6, no. 5, pp. G348-G358, 1982.

[52] B. J. R. Whittle, "Mechanisms underlying gastric mucosal damage induced by indomethacin and bile salts, and the actions of prostaglandins," British Journal of Pharmacology, vol. 60, no. 3, pp. 455-460, 1977.

[53] J. A. Selling, D. L. Hogan, and A. Aly, "Indomethacin inhibits duodenal mucosal bicarbonate secretion and endogenous prostaglandin E2 output in human subjects," Annals of Internal Medicine, vol. 106, no. 3, pp. 368-371, 1987.

[54] W. Toma, J. D. S. Gracioso, F. D. P. De Andrade, C. A. HirumaLima, W. Vilegas, and A. R. M. Souza Brito, "Antiulcerogenic activity of four extracts obtained from the bark wood of Quassia amara L. (Simaroubaceae)," Biological and Pharmaceutical Bulletin, vol. 25, no. 9, pp. 1151-1155, 2002.

[55] J. F. Pérez, M. C. Ruiz, and F. Michelangeli, "Simultaneous measurement and imaging of intracellular $\mathrm{Ca}^{2+}$ and $\mathrm{H}^{+}$transport in isolated rabbit gastric glands," Journal of Physiology, vol. 537, no. 3, pp. 735-745, 2001.

[56] M. Jan, A. Hussain, S. M. Naeem, S. A. Malik, R. Masood ur, and M. Hassan, "Comparison between the effects of of the extract of Myristica fragrans and cimetidine on the volume and acidity of carbachol-induced gastric secretion in fasting rabbits," Pakistan Journal of Medical Sciences, vol. 43, no. 4, pp. 191-194, 2004. 

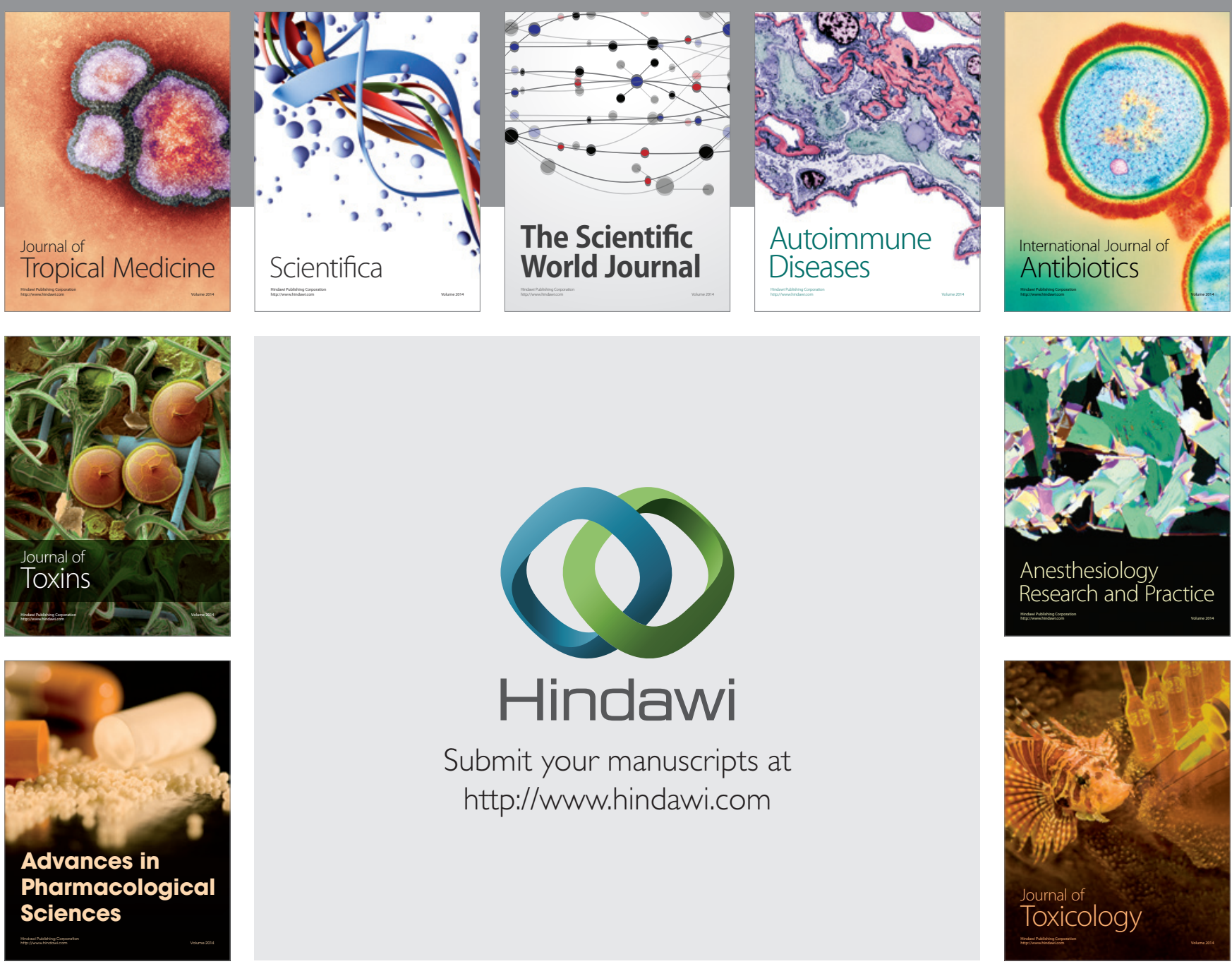

\section{Hindawi}

Submit your manuscripts at

http://www.hindawi.com
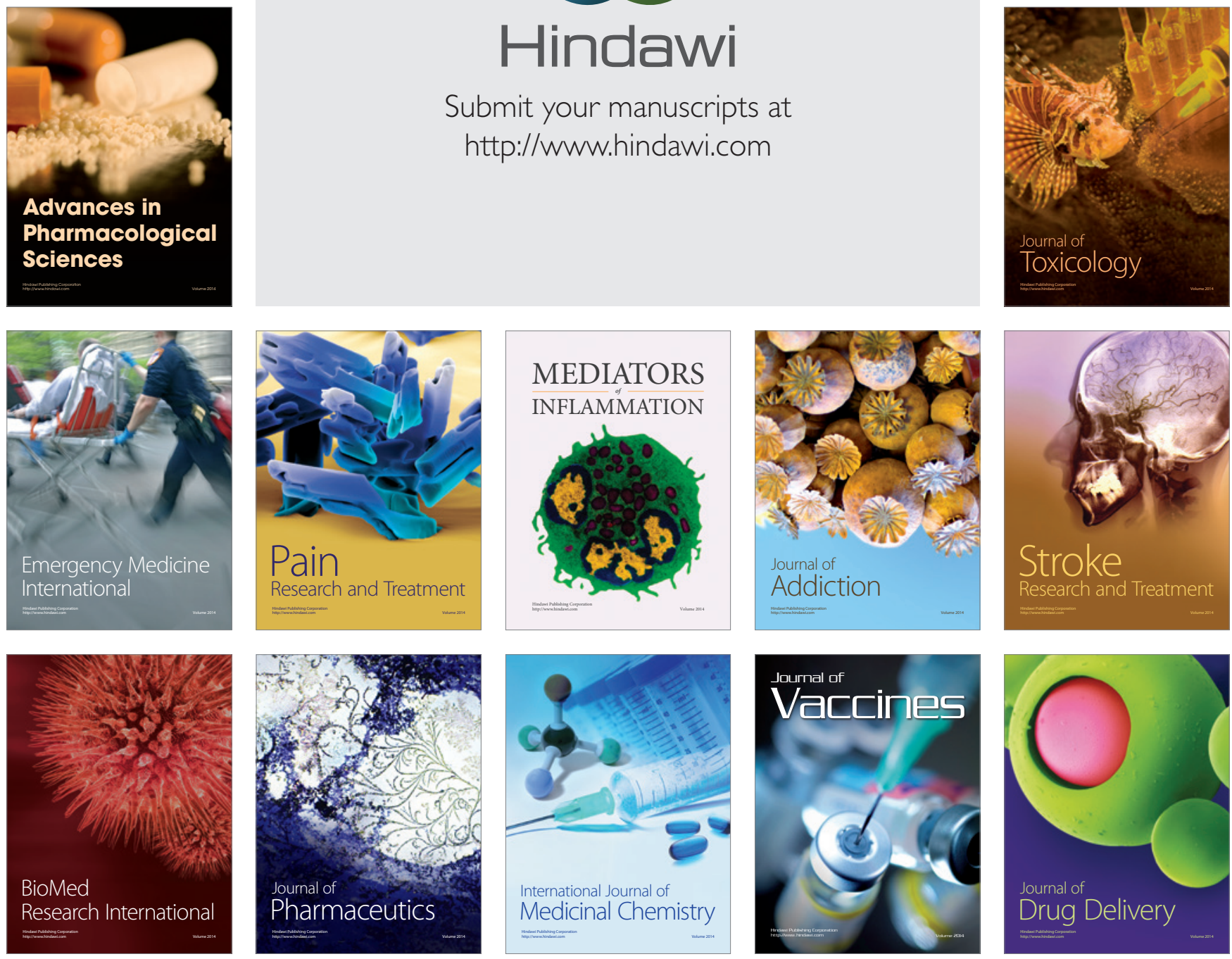